\title{
Mass propagation of Juniperus procera Hoechst. Ex Endl. From seedling and screening of bioactive compounds in shoot and callus extract
}

Abdalrhaman M. Salih ${ }^{1 *}$, Fahad Al-Qurainy ${ }^{1}$, Salim Khan ${ }^{1}$, Mohamed Tarroum¹, Mohammad Nadeem', Hassan O. Shaikhaldein ${ }^{1}$, Nadiyah M. Alabdallah' ${ }^{2}$ Saleh Alansi ${ }^{1}$ and Aref Alshameri ${ }^{1}$

\begin{abstract}
Background: Juniperus procera Hoechst. ex Endl. is a medicinal tree in Saudi Arabia, primarily in the Enemas region, but it is locally threatened due to die-back disease and difficulties regarding seed reproduction (seed dormancy and underdeveloped embryonic anatomy, and germination rate $<40 \%$ ). Hence, the alternative methods for reproduction of Juniperus procera are really needed for conservation and getting mass propagation for pharmaceutical uses.

Results: In this manuscript, we articulated the successful in vitro shoot multiplication and callus induction of J. procera by using young seedling as explants and detected an important antibacterial and antitumor product. Explants were grown on different types of media with the supplement of different combinations of Plant Growth Regulators (PGRs) at different concentrations. The best media for shoot multiplication was Woody Plant Media (WPM) supplemented with PGRs ( $0.5 \mu \mathrm{M}$ of IAA and $0.5 \mu \mathrm{M}$ BAP or $0.5 \mu \mathrm{M}$ IBA and $0.5 \mu \mathrm{M}$ BAP). Whereas for callus induction and formation Woody Plant Media (WPM) with the addition of PGRs ( $0.5 \mu \mathrm{M}$ 2,4-D and $0.5 \mu \mathrm{M}$ BAP) was better than the Chu Basal Salt Mixture (N6), Gamborg's B-5 Basal Medium (B5), and Murashige and Skoog media. The possibility of multiplication of J. procera in vitro creates significant advantages to overcome the difficulties of seeds dormancy for the reproduction of plants, conservation of trees, and getting mass propagation material for pharmaceutical studies. The shoot and callus extract of J. procera was detected using gas chromatography-mass spectrometry analysis and revealed more than 20 compounds related to secondary metabolites, which contained antibacterial and antitumor agents, such as ferruginol, Retinol, and Quinolone as well as confirmed by Direct Analysis in Real Time, Time of Flight Mass Spectrometry (DARTToF-MS). Podophyllotoxin (PTOX) was detected in callus material by HPLC with sigma standard and confirmed by DART-TOF-MS and UV spectra.

(Continued on next page)
\end{abstract}

\footnotetext{
* Correspondence: aabdalmola@ksu.edu.sa; abdalrahamanm@gmail.com

Abdalrhaman M. Salih has contributed significantly to this work

${ }^{1}$ Botany and Microbiology Department, College of Science King Saud

University, P. O. BOX 2455, Riyadh 11451, Saudi Arabia

Full list of author information is available at the end of the article
}

(C) The Author(s). 2021 Open Access This article is licensed under a Creative Commons Attribution 4.0 International License, which permits use, sharing, adaptation, distribution and reproduction in any medium or format, as long as you give appropriate credit to the original author(s) and the source, provide a link to the Creative Commons licence, and indicate if changes were made. The images or other third party material in this article are included in the article's Creative Commons licence, unless indicated otherwise in a credit line to the material. If material is not included in the article's Creative Commons licence and your intended use is not permitted by statutory regulation or exceeds the permitted use, you will need to obtain permission directly from the copyright holder. To view a copy of this licence, visit http://creativecommons.org/licenses/by/4.0/. The Creative Commons Public Domain Dedication waiver (http://creativecommons.org/publicdomain/zero/1.0/) applies to the data made available in this article, unless otherwise stated in a credit line to the data. 


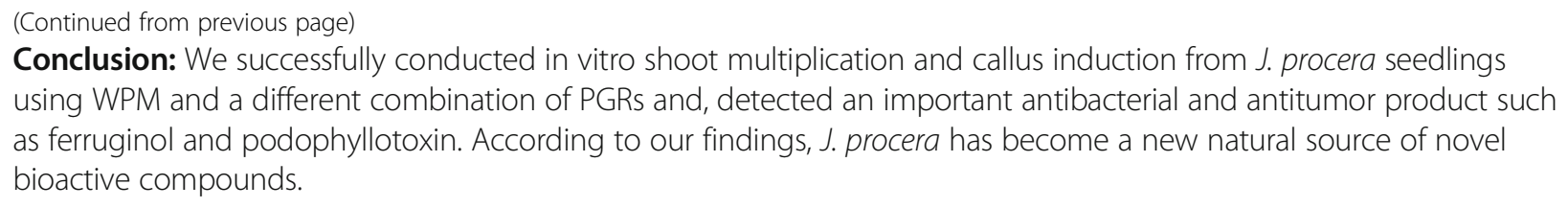

Keywords: Micropropagation, Podophyllotoxin, New compounds, Juniperus procera, Medicinal, Endanger plant, And DART-ToF-MS analysis

\section{Introduction}

The genus Juniperus $\mathrm{L}$. is the second most prevalent group of conifer s on Earth [1]. Juniperus procera is coniferous evergreen tree or shrub of the Cupressaceae family. There are over 75 species of Juniperus [2]. Juniperus procera occurs in south Saudi Arabia in the Enemas region, and it is commonly called "Arar" in Arabic. Juniperus procera is indigenous to the mountains of eastern Africa from east Sudan to Zimbabwe, and southwest of the Arabian Peninsula, and it is widely spread throughout southern part of Saudi Arabia [3]. Juniperus procera is a source of natural drugs with potential anticancer, antimicrobial, insecticidal and antioxidant activities [46]. The antifungal activity of resin from J. procera was tested against Pyrofomes demidoffii (Lév.) Kotl. and an impressive result was observed [7]. It was reported that the leaves of $J$. procera is source of new flavonoid [3]. Besides that, fruits have medicinal values for headaches and curing skin diseases. Its resin was used in combination with honey as a stimulant and medicine to treat ulcers and liver diseases [8-10]. Numerous constituents of J. procera extract were detected using GC/MS analysis and reduced synthesis of aflatoxin B2 and G2 [11]. Moreover, it has various economic, social, and ecological values [12]. Juniper species have been used for many purposes including wood, landscaping and medicinal purposes $[2,13-15]$. On the other hand, seed dormancy is a major hurdle for artificial regeneration of J. procera for economic and ecological importance [16]. In this context, it was reported that, some species of Juniperus have produced very small number of viable seeds or anatomically undeveloped [17]. Furthermore, the low number of fully developed seeds is one of the limitations of sexual reproduction in these trees $[18,19]$. Mainly, because of drought, soil erosion, and increased runoff, the species has been declining progressively in many parts of the world $[18,20]$. In some countries it is considered as an endangered tree [21]. The conservation strategies that have been used to date with traditional forestry techniques have not been satisfactory in many cases [16]. Since, very low potential for regeneration from seeds was reported. Thus, increasing attention has been paid to the possibilities offered by in vitro culture technology, which could be an alternative method for conservation and mass clonal propagation of different coniferous tree species [1]. In contrast, plant in vitro propagation is not limited by environment and seasons, and can overcome the problems of traditional breeding techniques. Hence, it become a reliable method for propagation of plants, especially, the production of endangered and rare species [22-26]. The first work on the in vitro propagation of juniper has been performed by Javeed and co-authors in 1980 [27]. A few studies have been done and reported on the subject of juniper in vitro propagation [2, 28-32]. Thus, in vitro propagation of juniper species should be exaggerated because, the micropropagation maybe the only alternative methods of the reproduction of this group of plants [1]. It should be prioritized for the possibility of conservation [33], and mass propagation for pharmaceutical uses. According to [34] plant tissue culture is an efficient approach to improve secondary metabolites production. Thus, due to the difficulty of $J$. procera regeneration through seeds, micropropagation technique can be employed to produce mass propagation material for pharmaceutical purposes, thereby natural regeneration through seeds in the wild will be maintained. Therefore, the primary objective of the study was the in vitro propagation of J. procera, to overcome the vegetative reproduction and seed regeneration problems. Secondly, the study aimed at the scanning of secondary metabolites, primarily, antibacterial and antitumor products for their economic importance.

\section{Materials and methods}

\section{Plant materials and establishment of in vitro culture}

In autumn 2019, young seedlings of four-year-old J. procera were collected from the botanic garden at the College of Food and Agricultural Sciences, King Saud University (origin from Elbaha region, southern part of Saudia Arabia). Firstly, the explants were washed with tap water for $5 \mathrm{~min}$. Then, they were immersed in Clorox $25 \%(\mathrm{v} / \mathrm{v})$ for $20 \mathrm{~min}$ and washed three times with sterile distilled water under the sterile flow of a laminar flow cabinet. Cutting about $1 \mathrm{~cm}$ contained at least one axillary bud from the terminal shoots of the seedlings of four-year-old of Juniperus. procera were used as explants for in vitro propagation. 


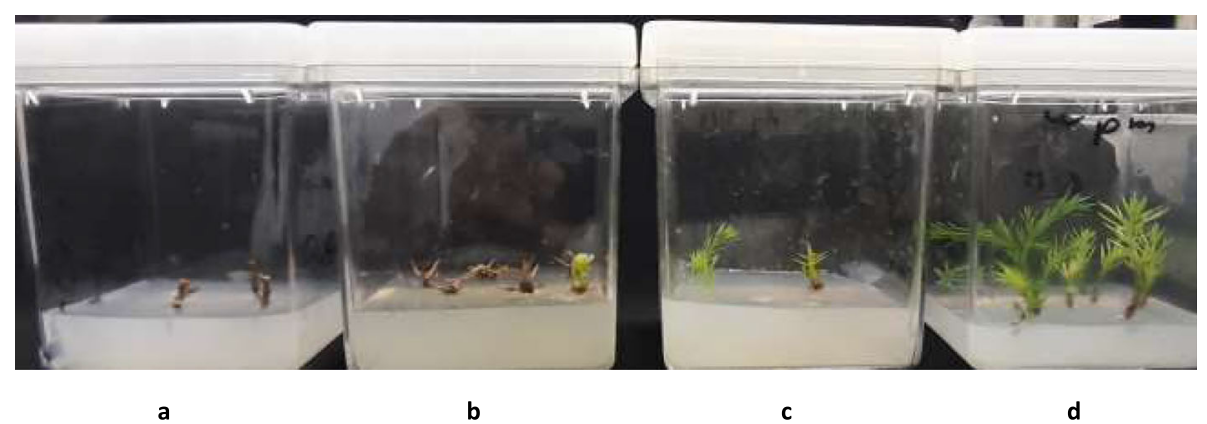

Fig. 1 In vitro growth of Juniperus procera explants on different types of media (a): B5 (0.1 cm), (b): N6 (0.2 cm), (c) MS (0.4) and (d) Woody Plant Medium) (scale bar $=0.7 \mathrm{~cm}$ ) after five weeks of growth

\section{Media and plant growth regulators for shoot multiplication}

Four types of media were tested to evaluate the effects of Plant Growth Regulators (PGRs) and media compositions on shoot multiplication: (1) Woody Plant Medium (WPM) [35], (2) Murashige and Skoog (MS) medium [36], (3) Gamborg's B-5 Basal Medium (B5 medium) [37], and (4) Chu Basal Salt Mixture (N6 medium) [38] (Fig. 1). Each was supplemented with combinations of PGRs, sucrose as carbon source $(30 \mathrm{~g} / \mathrm{L}), 7 \mathrm{~g} / \mathrm{L}$ of agar, and the $\mathrm{pH}$ was adjusted to 5.7 before autoclaving at $121^{\circ} \mathrm{C}$ for $20 \mathrm{~min}$. Then, for each treatment four explants (three jars per treatment, in total 576 explants) were cultured under laminar conditions. Multiplication rate of the average number of shoots, the average number of branches, average of plant height and survival rate were recorded after five months of growth (Table 2).

\section{Callus induction}

The explants (in total, 360) were sterilized as mentioned above. Then, inoculated into B5, MS, WPM, and N6 with different combinations and concentrations of PGRs (Table 2). In each treatment three replicates were used with three explant per jar. The jars were incubated in growth chamber at $25^{\circ} \mathrm{C} \pm 1$, in the dark conditions, for three months.

\section{Preparation of shoot and callus extracts for gas chromatography-mass spectrometry analysis}

$100 \mathrm{mg}$ shoot and callus of $J$. procera were lyophilized before placed in a pestle mortar and ground in $20 \mathrm{ml}$ of $25 \mathrm{mM}$ potassium phosphate buffer, with a $\mathrm{pH}$ of 7.0. The homogenate was transferred in a $100 \mathrm{ml}$ conical flask and was shaken for $30 \mathrm{~min}$ at room temperature. Then, $20 \mathrm{ml}$ of ethyl acetate was added, the mixture was incubated at room temperature for $5 \mathrm{~min}$. Then, organic and aqueous phases were separated by centrifugation at $5000 \mathrm{rpm}$ for $5 \mathrm{~min}$. The organic phase was collected and evaporated in a vacuum. The residue was reconstituted with $1 \mathrm{ml}$ of methanol and analyzed using gas chromatography-mass spectrometry (GC-MS 7890A; Agilent Technologies, USA) equipped with a 5975 massselective detector and a 7693 automated liquid sampler, fitted with a DB-5MS GC column (30 m length, $0.25 \mathrm{~mm}$ inner diameter, and $0.25 \mu \mathrm{m}$ film thickness).

\section{Direct analysis in real time, time of flight mass spectrometry (DART-ToF-MS)}

The extract samples were submitted to characterization by DART-ToF-MS analysis. The mass spectrometer instrument was AccuTOF LC-plus from JEOL (Japan). The volatile components of the extract were evaporated in a stream of helium heated at $250^{\circ} \mathrm{C}$, then ionized by the excited metastable helium atoms, before entering the ion source of the time of flight mass spectrometer. In the positive ionization mode, the molecules were mainly protonated without any fragmentation. The experimental conditions used for analysis of extract by DARTToF-MS are listed in (Table 1).

\section{Chromatographic analysis of Podophyllotoxin}

The identification of podophyllotoxin in callus and shoots of Juniperus procera was carried out on Agilent liquid chromatographic system controlled by G 4226A software. The column used for separation was a SB-C18 $(1.8 \mu \mathrm{m}, 4.6 \times 150 \mathrm{~mm})$. The mobile phase was consisted

Table 1 The conditions used for analysis of extract by DARTToF-MS

\begin{tabular}{ll}
\hline Parameter & Value \\
\hline Vacuum (Pirani gauge) & $1.8 \times 10^{+2} \mathrm{~Pa}$ \\
Vacuum (Analyzer) & $1.3 \times 10^{-5} \mathrm{~Pa}$ \\
Heater temperature & $250^{\circ} \mathrm{C}$ \\
lonization mode & Positive \\
Injection gas & Helium \\
Ring lens voltage & $4 \mathrm{~V}$ \\
Orifice 1 voltage & $10 \mathrm{~V}$ \\
Orifice 2 voltage & $5 \mathrm{~V}$ \\
\hline
\end{tabular}


Table 2 Effect of plant growth regulators combinations and Woody Plant Media on shoot proliferation of Juniperus procera after five months of growth

\begin{tabular}{|c|c|c|c|c|}
\hline $\begin{array}{l}\text { Concentrations of PGRs } \\
(\mu \mathrm{M})\end{array}$ & $\begin{array}{l}\text { Average of shoots } \\
\text { number }\end{array}$ & $\begin{array}{l}\text { Average number of branches } \\
\text { (shoot }^{-1)}\end{array}$ & $\begin{array}{l}\text { Average of shoots length } \\
(\mathrm{cm})\end{array}$ & $\begin{array}{l}\text { Survival rate } \\
(\%)\end{array}$ \\
\hline 2,4.D + BAP (00: 0.00) & $3.00 \pm 0.00^{\mathrm{ab}}$ & $1.67 \pm 0.33^{c}$ & $2.83 \pm 0.16^{\mathrm{ab}}$ & 72.0 \\
\hline 2,4.D + BAP(0.25: 0.25) & $2.67 \pm 0.33^{b}$ & $1.33 \pm 0.33^{c}$ & $2.33 \pm 0.33^{b}$ & 66.0 \\
\hline 2,4.D + BAP (0.25: 0.5) & $2.00 \pm 0.57^{b}$ & $1.67 \pm 0.33^{c}$ & $3.00 \pm 0.57^{\mathrm{ab}}$ & 50.0 \\
\hline 2,4.D + BAP (0.25: 1.0) & $2.66 \pm 0.33^{b}$ & $1.67 \pm 0.33^{c}$ & $2.83 \pm 0.16^{\mathrm{ab}}$ & 66.0 \\
\hline 2,4.D + BAP(0.5: 0.25) & $2.33 \pm 0.66^{b}$ & $2.33 \pm 0.33^{c}$ & $2.33 \pm 0.33^{b}$ & 72.0 \\
\hline 2,4.D + BAP (0.5: 0.5) & $2.00 \pm 0.57^{b}$ & $1.33 \pm 0.33^{c}$ & $2.17 \pm 0.16^{b}$ & 50.0 \\
\hline 2,4.D + BAP (0.5: 1.0) & $2.33 \pm 0.33^{b}$ & $2.00 \pm 0.00^{c}$ & $2.67 \pm 0.16^{b}$ & 58.0 \\
\hline 2,4. D + BAP (1.0: 0.25) & $2.00 \pm 0.57^{b}$ & $1.33 \pm 0.33^{c}$ & $2.33 \pm 0.33^{b}$ & 50.0 \\
\hline 2,4.D + BAP (1.0: 0.5) & $2.67 \pm 0.33^{b}$ & $1.67 \pm 0.33^{c}$ & $2.17 \pm 0.16^{b}$ & 66.0 \\
\hline 2,4. D + BAP (1.0: 1.0) & $3.00 \pm 0.00^{\mathrm{ab}}$ & $1.67 \pm 0.33^{c}$ & $2.33 \pm 0.33^{b}$ & 72.0 \\
\hline IAA + BAP (0.5: 0.5) & $4.00 \pm 0.00^{\mathrm{a}}$ & $14.00 \pm 1.7^{\mathrm{a}}$ & $4.00 \pm 0.57^{\mathrm{ab}}$ & 100 \\
\hline IBA + BAP(0.5: 0.5) & $4.00 \pm 0.00^{a}$ & $10.67 \pm 2.6^{\mathrm{b}}$ & $5.33 \pm 0.88^{\mathrm{a}}$ & 100 \\
\hline
\end{tabular}

The data are presented the average of shoots, branches per shoot, average of shoot length \pm standard error, and Survival rate (\%).

$a, b, c$ Means within the same column with different superscripts differ significantly $(P<0.05)$

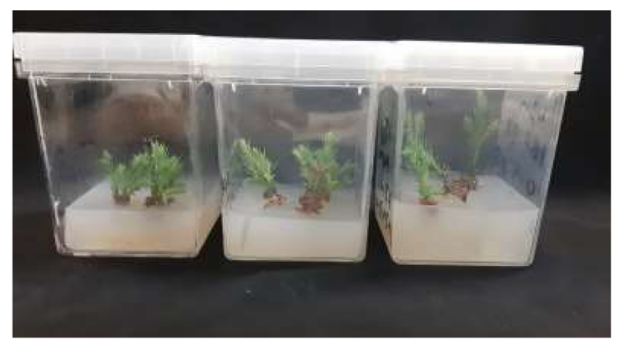

a

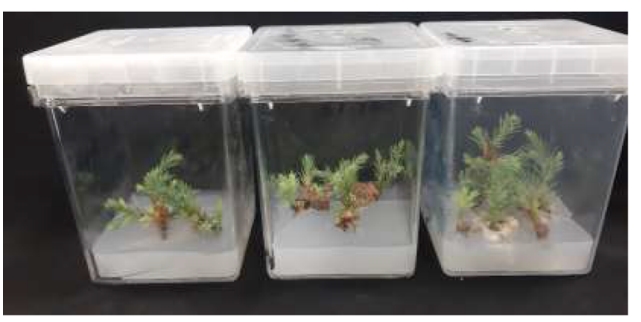

c

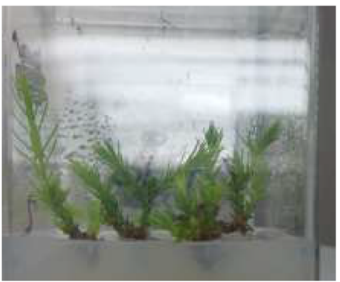

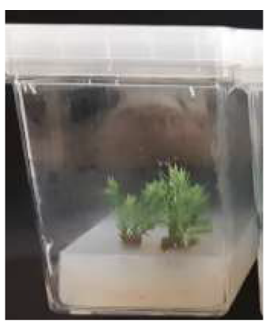

b
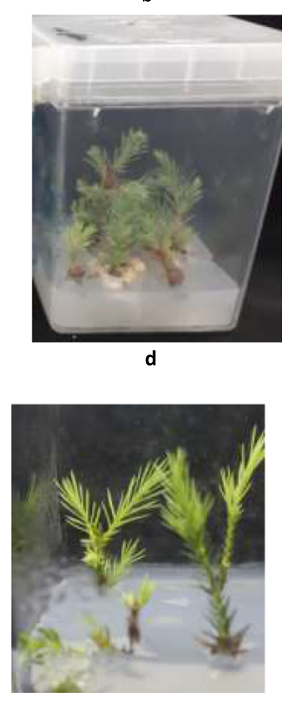

Fig. $\mathbf{2}$ a \& b: Effect of the combination of IBA and BAP on shoot multiplication of Juniperus procera on Woody Plant medium (WPM) (scale bar $=$ $1.1 \mathrm{~cm}$ ). $\mathbf{c} \& \mathbf{d}$ : Effect of the combination of IAA and BAP on shoot multiplication of J. procera on WPM (scale bar $=1.0 \mathrm{~cm}$ ). e \& $\mathbf{f}$ : Effect of 2,4-D and BAP on shoot perforation of J. procera on WPM (scale bar $=0.75 \mathrm{~cm}$ ) after five months 
of MilliQ water (solvent A) and methanol (solvent B). The composition of the mobile phase was 30:70 (v/v). Detection was performed at $290 \mathrm{~nm}$. Podophyllotoxin were initially identified by comparison of their retention times of standard and confirmed by UV spectra using SHIMADZU SPECTROPHOTOMETER (UV - 1800) in the range of $200-400 \mathrm{~nm}$.

\section{Statistical analysis}

Data from shoot proliferation and callus production were analyzed using one way of analysis of variance, which is a comparison based on a completely randomized design. A $P$-value $<0.05$ was considered as statistically significant. The Duncan test was used to determine which treatments were different at $(p<0.05)$ using SPSS Version 20-32 bit (IBM, USA).
Table 3 Effect of plant growth regulators combinations and different types of media on callus formation of Juniperus procera

\begin{tabular}{|c|c|c|c|c|c|c|}
\hline \multirow{2}{*}{\multicolumn{2}{|c|}{$\begin{array}{l}\text { BAP }(\mu \mathrm{M}) \\
2,4-D(\mu \mathrm{M})\end{array}$}} & \multicolumn{4}{|c|}{ Callus formation } & \multirow{3}{*}{$\begin{array}{l}\begin{array}{l}\text { Callus } \\
\text { weight }(\mathrm{g})\end{array} \\
0.0\end{array}$} \\
\hline & & \multirow{2}{*}{$\frac{\text { MS }}{-}$} & \multirow{2}{*}{$\begin{array}{l}\text { WPM } \\
-\end{array}$} & \multirow{2}{*}{$\frac{\text { B5 }}{-}$} & \multirow{2}{*}{$\begin{array}{l}\text { N6 } \\
-\end{array}$} & \\
\hline 0.0 & 0.0 & & & & & \\
\hline 0.25 & 0.25 & - & - & - & - & 0.0 \\
\hline 0.25 & 0.5 & - & * & - & - & 1.0 \\
\hline 0.25 & 1.0 & & $*$ & & - & 0.4 \\
\hline 0.5 & 0.25 & - & - & - & - & 1.0 \\
\hline 0.5 & 0.5 & & $* * *$ & - & - & 4.6 \\
\hline 0.5 & 1.0 & & $* *$ & & & 3.1 \\
\hline 1.0 & 0.25 & & - & - & - & 0.0 \\
\hline 1.0 & 0.5 & & $*$ & - & - & 1.0 \\
\hline 1.0 & 1.0 & * & - & - & - & 1.0 \\
\hline
\end{tabular}

---: no callus induction, ${ }^{*}:=$ Poor, ${ }^{* *}:$ Fair, ${ }^{* * *}$ : Good.

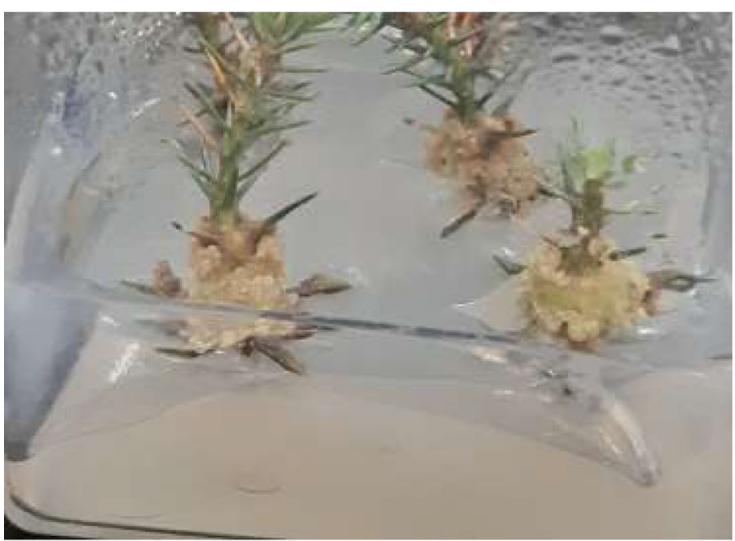

a

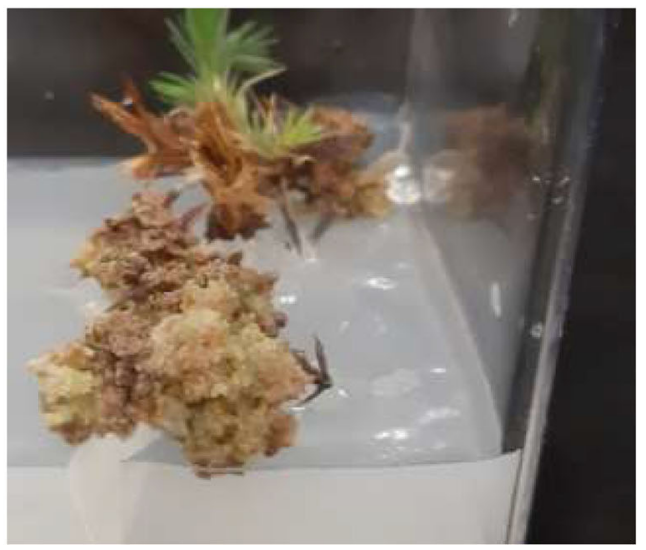

C

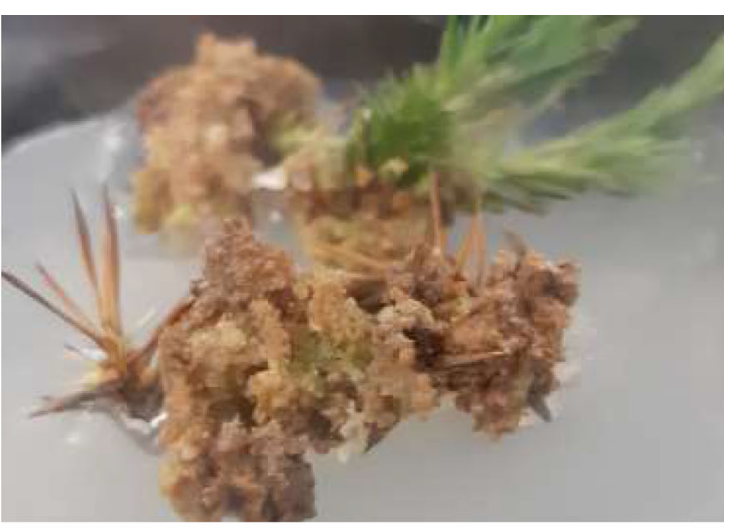

b

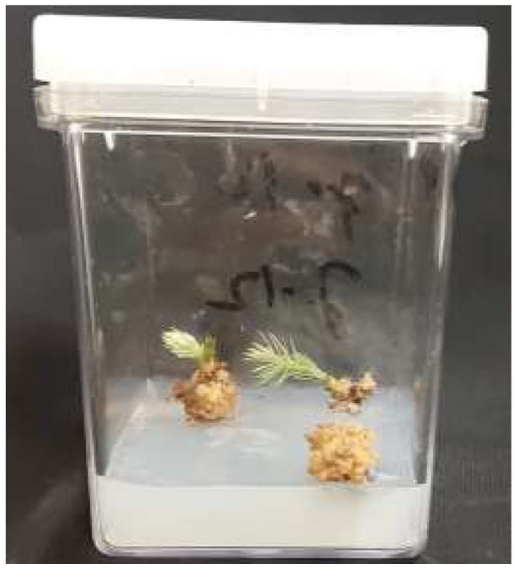

d

Fig. 3 a, b \& c: Effect of the combination of (2,4-D and BAP - 0.5: 0.5) on callus induction and formation from Juniperus procera on Woody Plant medium (WPM) (scale bar $=0.1$, initiation of callus, while $b \& c=0.5 \mathrm{~cm})$, $\mathbf{d}$ : Effect of the combination of $(2,4-D$ and BAP; 1.0:1.0) on callus induction and formation from Juniperus procera on MS medium (scale bar $=0.2$ ) 


\section{Results and discussion}

Plant materials and disinfection

No problems were faced in relation to contamination during experiment. Many researchers have reported that there have been no problems with contamination during Juniperus spp., In vitro propagation when different fragments of plants have been used as the initial explants [33, 39]. According, to literature review, the best method of juniper explants for establishing a culture contaminationfree is plant material derived from in vitro growing explants, because they do not require any procedure of sterilization [40, 41] which are in agreement with our findings.

\section{Shoot multiplication}

The effect of the culture of shoot multiplication was evaluated by comparing the response of shoots in different treatments: the morphological characters of shoot, survival rate, shoot number, shoot length, and the number of branches per shoot was evaluated for each treatment. The data on shoots multiplication were collected after five months of multiplication and by comparing

Table 4 Some phytochemical constituents of in vitro shoots and calli of Juniperus procera detected by GC-MS and their biological activity

\begin{tabular}{|c|c|c|c|c|c|}
\hline Shoot-Compounds & RT (min) & Activity & Callus - compounds & RT (min) & Activity \\
\hline Cyclononasiloxane & $27.214-31.660$ & Antibacterial [45] & $\begin{array}{l}\text { 2,4,6-Cycloheptatrien- } \\
\text { 1-one }\end{array}$ & 18.406 & Bacteriostatic and bactericidal [46] \\
\hline S-Indacene-1,7-dione & 33.548 & Antifungal [47] & $\begin{array}{l}\text { 1H-Cycloprop } \\
\text { [e]azulene }\end{array}$ & 21.259 & $\begin{array}{l}\text { Analgesic and anti-inflammatory } \\
\text { [48] }\end{array}$ \\
\hline Perylene & 34.252 & $\begin{array}{l}\text { Potentially mutagenic and } \\
\text { carcinogenic }[49,50]\end{array}$ & 1H-Benzocycloheptene & 21.259 & $\begin{array}{l}\text { Anti-tumor, anti-inflammatory, } \\
\text { and antimicrobial [51] }\end{array}$ \\
\hline Benzoic acid & 35.813 & $\begin{array}{l}\text { Antimicrobial [52], } \\
\text { ant hepatotoxic [53] and } \\
\text { fungitoxic [54] }\end{array}$ & Cyclononasiloxane & 27.214 & Antibacterial [45] \\
\hline 1Phenanthrenecarboxaldehyde & 36.677 & Antimicrobial [55] & Kaur-16-ene & 30.905 & Anti-inflammatory [47] \\
\hline Retinol & 36.677 & $\begin{array}{l}\text { Photoaging and dermatologic } \\
\text { disorders [56-58] }\end{array}$ & $\begin{array}{l}\text { Podocarpa-6,8,11,13- } \\
\text { tetraen-12-ol }\end{array}$ & 30.905 & Algicidal [59] \\
\hline 2-Phenanthrenol & 38.891 & Antimicrobial [60] & Phenanthrene & 33.548 & $\begin{array}{l}\text { Anti-inflammatory, antiallergic, } \\
\text { antimicrobial,cytotoxic, } \\
\text { antiplatelet aggregation } \\
\text { and phytotoxic [61-64] }\end{array}$ \\
\hline n-Octanoic acid & 39.118 & $\begin{array}{l}\text { Anti-inflammatory and } \\
\text { anti-seizure [65] }\end{array}$ & S-Indacene-1,7-dione & 33.548 & Antibacterial [60] \\
\hline Ferruginol & $39.227-39.865$ & $\begin{array}{l}\text { Antibacterial, antimalarial } \\
\text { and antitumoral [62-64] }\end{array}$ & Adipic acid & 34.009 & $\begin{array}{l}\text { a precursor for Nylon-6, and } 6 \\
\text { polymer [61] }\end{array}$ \\
\hline Prasterone & 40.091 & $\begin{array}{l}\text { vulvovaginal atrophy } \\
\text { treated [62] }\end{array}$ & Desomorphine & 36.677 & Analgesic [63] \\
\hline n-Nonadecanoic acid & 40.586 & Antimicrobial [64] & Benz [c]acridine, & 38.254 & Antibacterial $[69,70]$ \\
\hline 9(1H)-Phenanthrenone & 41.02 & Antifungal [71] & Acetamide & 38.254 & $\begin{array}{l}\text { Antifungal [71], Anti-inflammatory } \\
\text { and analgesic [72] }\end{array}$ \\
\hline 2,6-Phenanthrenediol & 42.507 & Antimicrobial [73] & $\begin{array}{l}\text { Podocarpa-8,11,13- } \\
\text { triene }\end{array}$ & 38.480 & Anti-inflammatory [74] \\
\hline \multirow[t]{8}{*}{ Quinolone } & 43.329 & Antibiotic $[71,72,75]$ & Phenanthrenol & 38.480 & Drug precursor [76] \\
\hline & & & Fluorophenol & 38.623 & antibacterial [77] \\
\hline & & & Ferruginol & $\begin{array}{l}39.277- \\
39.865\end{array}$ & $\begin{array}{l}\text { Antibacterial, antimalarial and } \\
\text { antitumor [66-68] }\end{array}$ \\
\hline & & & 2-Phenanthrenol & 39.277 & antimicrobial [60] \\
\hline & & & Acetamide & 39.705 & $\begin{array}{l}\text { Anti-inflammatory and } \\
\text { Analgesic [78] }\end{array}$ \\
\hline & & & $\begin{array}{l}\text { Benzene(1-nitro-4- } \\
\text { (phenylmethyl) }\end{array}$ & 39.865 & inhibitor [78] \\
\hline & & & Cyclopenta & 40.527 & Antitumor [79] \\
\hline & & & 9(1H)-Phenanthrenone & 41.039 & anti-inflammatory [80] \\
\hline
\end{tabular}




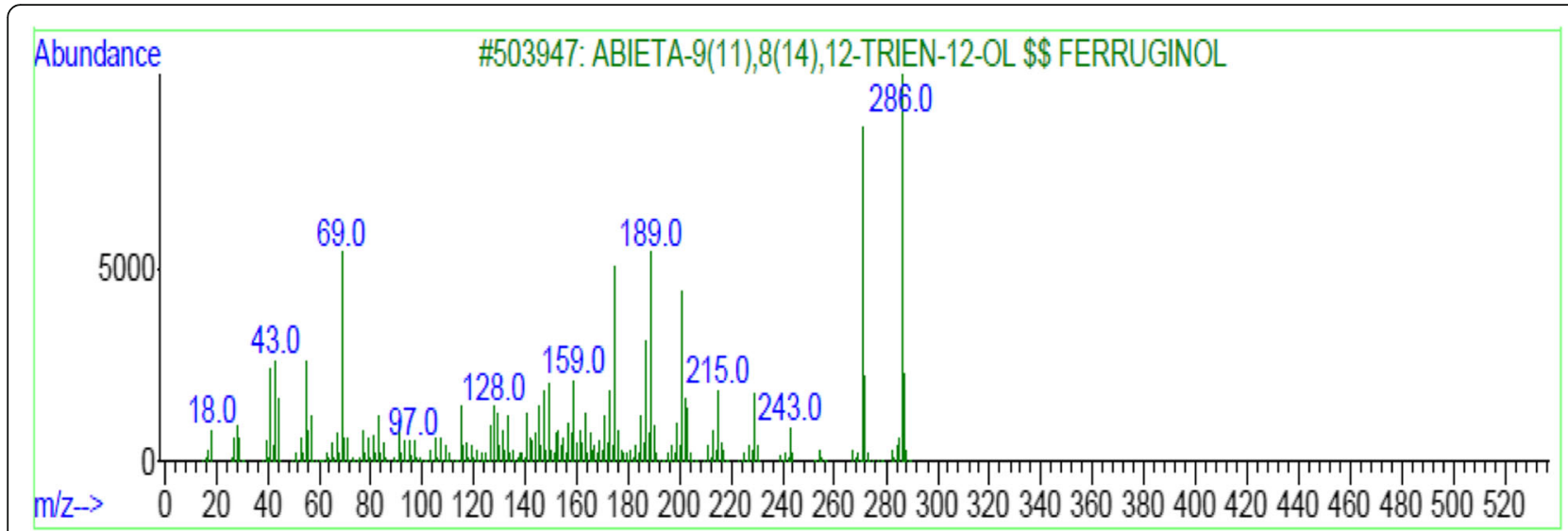

Fig. 4 GC-MS of in vitro shoot and callus extract of Juniperus procera showing the ferruginol spectrum

explants response on all media. After three weeks of culturing, the color of explants in MS, B5, and N6 media changed from green to yellow (Fig. $1 \mathrm{a}, \mathrm{b}$ and c). Two weeks later, these cultures were excluded due to necrosis of explants, and the data were discarded from statistical analysis (Table 2). Shoots form Juniperus phoenicea L. growing on MS medium showed browned and necrotic zones reported by [2]. Data in Table 2 show the average number of shoots, average of shoot length growth, average of branches per shoot and survival rate on WPM with supplements of different combinations and concentration of PGRs. The explants successfully produced several new shoots over six weeks, which indicates that the best media was WPM. The highest average number of shoots regenerated from original explants was obtained on WPM with IAA $(0.5 \mu \mathrm{M})$ and $(0.5 \mu \mathrm{M})$ BAP (Table 2 and Fig. $2 \mathrm{c} \& \mathrm{~d}$ ). While, the longest average shoot length was achieved on WPM with IBA $(0.5 \mu \mathrm{M})$ and BAP $(0.5 \mu \mathrm{M})$ (Table 2 and Fig. 2 a \& b). Whereas, among 2,4-D and ABP combinations on WPM, (1.0:1.0) concertation was the best (Table 2 and Fig. 2 e \& f). Shoots induction from juniper species explants ranged between 4 to 12.9 per explant for Juniperus navicularis Gand. and Juniperus thurifera L. respectively, reported by [31, 39]. In our study, the best shoots induction per explant about 14 by using WPM with IAA $(0.5 \mu \mathrm{M})$ and BAP $(0.5 \mu \mathrm{M})$ (Table 2 and Fig. 2 c \& d). Khater [31] who has been reported that, the best elongation of shoots of Juniperus thurifera L., has been achieved on WPM with supplemented of $0.5 \mathrm{mg} \mathrm{L}^{-1}$ of BAP and 0.25 or $1 \mathrm{mg} \mathrm{L}^{-1}$ of 2,4-D. We observed that the combination of IBA and BAP or IAA and BAP had an important effect on vigorous growth, the development of shoots, survival rate, and elongated shoots compared with other PGRs combinations on WPM. Thus, is a significant point for mass propagation and conservation of this species. No report was found in the literature regarding J. procera shoot multiplication in vitro. In general,

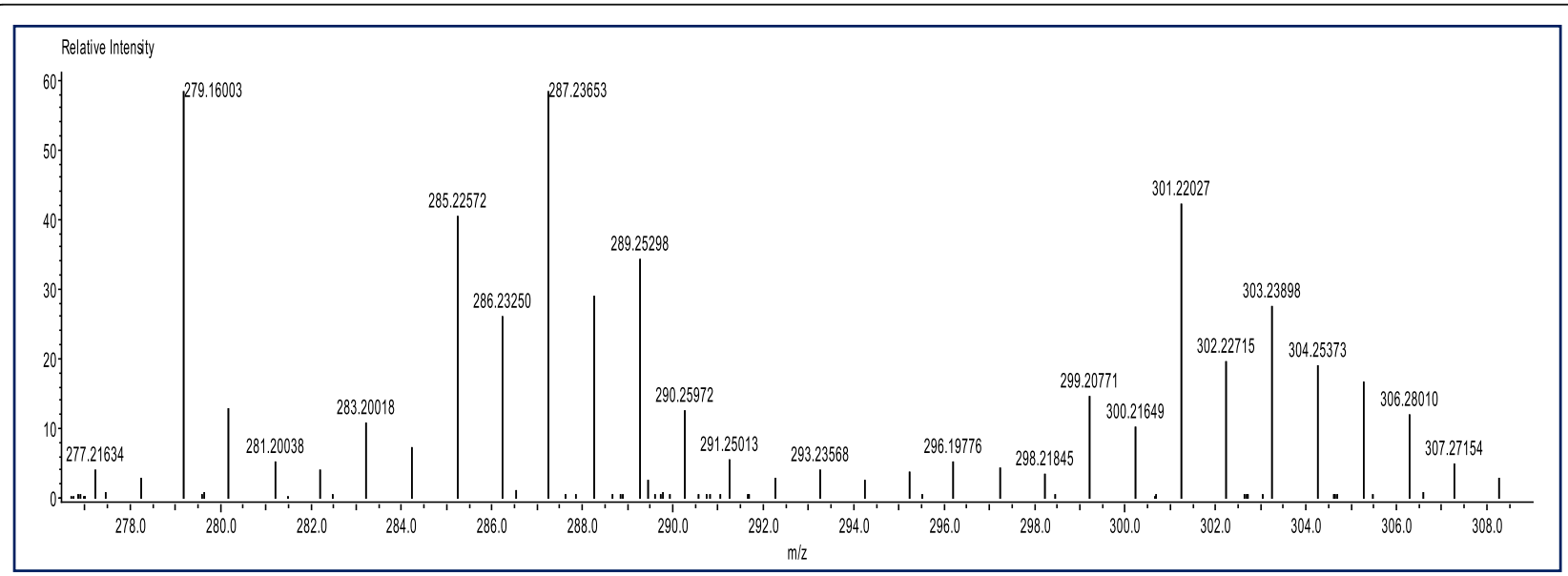

Fig. 5 DART TOF-MS of in vitro shoot extract of Juniperus procera showing the ferruginol spectrum 


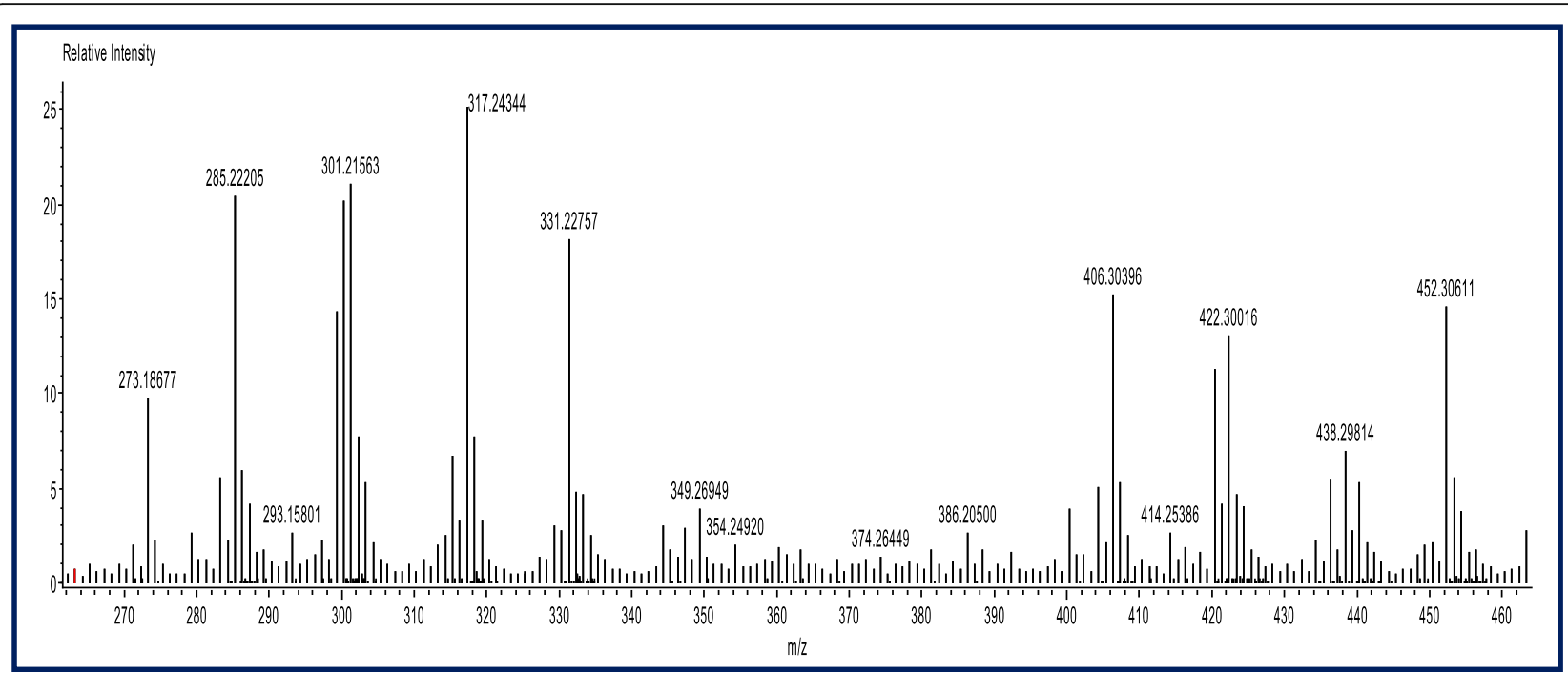

Fig. 6 DART TOF-MS of in vitro callus extract of Juniperus procera showing the ferruginol spectrum

juniper species respond to low levels of cytokine and auxin [30]. For example, the concentration of BAP at $0.5 \mathrm{mg} \mathrm{L}^{-1}$ in WPM was the best for the shoots multiplication of three juniper species (Juniperus excels M.Bieb., Juniperus horizontalis Moench. and Juniperus chinensis Roxb.) reported by [2].

\section{Callus induction}

Data in Table 3 show the influence of PGRs supplemented in WPM, B5, N6 and MS medium. The earliest sign of callus induction was noticeable after five weeks of incubation (Fig. 3 a). The amount of produced callus, percentage of calli induction was significantly different among treatments, for example, the produced amount of calli per treatment was ranged between 0.4 to $4.6 \mathrm{~g}$. Which indicate that, among each treatment, the best callus type and callus induction rate (4.6 g) was in WPM with the addition of $0.5 \mu \mathrm{M}$ BAP and $0.5 \mu \mathrm{M}$ 2,4-D (Table 3 and Fig. 3 b, c) and less effective callus induction rate $(0.4 \mathrm{~g})$ was obtained using WPM supplemented with $(0.25 \mu \mathrm{M}) 2$,4-D and $(1.0 \mu \mathrm{M})$ BAP. While, in MS media, one combination $(1.0 \mu \mathrm{M} \mathrm{BAP}+1.0 \mu \mathrm{M}$ 2,4-D) out of all PGRs combinations was induced callus $1.0 \mathrm{~g}$ (Table 2 and Fig. 3 d). Whereas, N6 and B5 media with the same PGRs combinations did not induce the callus and was excluded. The best callus quality from $J$. thurifera was achieved on WPM supplemented with either $0.5 \mathrm{mg} \mathrm{L}^{-1} \mathrm{BAP}+0.25 \mathrm{mg} \mathrm{L}^{-1}$ 2,4-D or $0.25 \mathrm{mg} \mathrm{L}-1132$ $\mathrm{BAP}+0.25 \mathrm{mg} \mathrm{L}^{-1}$ 2,4-D [31]. Moreover, the best induced callus from Juniperus species (Juniperus excelsa, Juniperus horizontalis, and Juniperus chinensis) is obtained in WPM medium with $0.50 \mathrm{mg} / \mathrm{L}$ of BAP and $0.50 \mathrm{mg} / \mathrm{L}, 2,4-\mathrm{D}$ [28]. In turn, in coniferous species, an appropriate ratio of auxin and cytokinin is requested to stimulate the calli from explants reported by [1]. Although, Muranaka [42] stated that, callus was induced from Juniperus chinensis after application of higher concentrations of NAA $\left(3.0 \mathrm{mg} \mathrm{L}^{-1}\right)$ and $\mathrm{KIN}\left(0.2 \mathrm{mg} \mathrm{L}^{-1}\right)$. The color of produced calli changed to a brownish but, sub-culturing over 20 days eliminated this problem. It is known that the induced calli may quickly turn brownish in juniper species [1].

Table 5 Main constituents (1.25-1.60 min) of in vitro shoot extract of Juniperus procera detected by DART-ToF-MS.

\begin{tabular}{lllllll}
\hline $\mathbf{N}^{\mathbf{0}}$ & Experimental mass & Calculated mass & $\begin{array}{l}\text { Mass difference } \\
(\mathbf{m m u})\end{array}$ & Formula & Unsaturation degree & Possible Compound \\
\hline 1 & 285.22572 & 285.22184 & 3.88 & $\mathrm{C}_{20} \mathrm{H}_{29} \mathrm{O}$ & 6.5 & Ferruginol \\
2 & 286.23250 & 286.22966 & 2.84 & $\mathrm{C}_{20} \mathrm{H}_{30} \mathrm{O}$ & 6.0 & \\
3 & 287.23653 & 287.23749 & -0.96 & $\mathrm{C}_{20} \mathrm{H}_{31} \mathrm{O}$ & 5.5 & Podocarp-7-en-33-ol \\
4 & 288.24612 & 288.24531 & 0.81 & $\mathrm{C}_{20} \mathrm{H}_{32} \mathrm{O}$ & 5.0 & \\
5 & 289.25298 & 289.25314 & -0.16 & $\mathrm{C}_{20} \mathrm{H}_{33} \mathrm{O}$ & 4.5 & kauren-19-ol \\
6 & 290.25972 & 290.25649 & 3.23 & $\mathrm{C}_{19}{ }^{13} \mathrm{CH}_{33} \mathrm{O}$ & 4.5 & \\
\hline
\end{tabular}


Gas chromatography-mass spectrometry analysis of shoot and calli of Juniperus procera extract

In general, plants produce secondary metabolites as a protection mechanism against biotic and abiotic stress. On the other hand, it has been showed that, the in vitro propagation is a tool for secondary metabolites production, that can ultimately provide a continuous, reliable source of bioactive compounds. Moreover, a rapid production of important secondary metabolites can be achieved through micro-propagation technique [34, 43, 44]. The identification of the constituents in the extract was performed using commercial libraries and comparison of mass spectra, matches percentage, and retention times of reference compounds. GC-MS analysis of shoots and calli of $J$. procera extract revealed more than 20 constituents related to secondary metabolites (Table 4). But, variation has observed between shoot and calli extract (Table 4). These detected compounds are containing antimicrobial and antitumor agents, one of which is ferruginol (Fig. 4). The typical positive ion spectra obtained from calli and shoots of J. procera with molecular formula $\left(\mathrm{C}_{20} \mathrm{H}_{30} \mathrm{O} \pm \mathrm{H}\right)$ and $\mathrm{m} / \mathrm{z} 286$ ion was detected in calli and shoots (Fig. 4). Which is closely matches ferruginol $\left(\mathrm{C}_{20} \mathrm{H}_{30} \mathrm{O}\right.$, mol. wt 286.5) and corresponds well with NIST Standard Reference Database 1A [81]. In accordance, the peaks generated by ferruginol are normally 285 and 301 [82]. Ferruginol is a diterpene phenol, has received attention recently, for its pharmacological properties, including antibacterial, anti-tumor, gastro-protective and cardio-protective effects [66]. In addition, ferruginol inhibits the growth rate of cancer cells [67]. Moreover, ferruginol compounds tested against malaria strains 3D7 and K1 and some structure activity relationships were identified for antimalarial activity [68]. The second important compound is retinol (vitamin A). Retinol belongs to a family of endogenous natural retinoids and is a precursor for the synthesis of retinoic acid and retina. Retinol has playing an effective role in treating aging and photoaging, recounted by [83]. The third important compound is Quinolone, which is an antibiotic containing a bicyclic core structure [84]. Moreover, it has been reported that Quinolones are a class of antibactericidal and antibiotics with broad- spectrum activity, which can inhibit both Gram-positive and Gram-negative bacteria [75]. Although J. procera has been investigated widely as a source of natural drugs with anticancer, antioxidant, insecticidal potential and antimicrobial activities [6-8]. No available report has been found in literature related to J. procera in vitro propagation and secondary metabolites detection. The screening of natural $J$. procera extract reflect the presence of 46 secondary metabolite reported by [11]. It's totally different from the constituents which revealed by the present study. While [83] has mentioned that the stem bark of $J$. procera grown in Saudi Arabia has yielded several antimicrobial diterpenes such as ferruginol. Moreover, two known abietanes (totarol and ferruginol) have been identified from berries of Juniperus procera, Juniperus excelsa and Juniperus phoenicea [45]. Besides the most important bioactive compounds described and highlighted above. The others phytochemical constituents detected in the shoots and callus extract of Juniperus procera and their activities are presented in Table 4.

\section{Direct analysis in real time, time of flight mass spectrometry of shoot and callus extract of $J$. procera}

The in vitro shoot and callus extracts were submitted to characterization by DART-ToF-MS analysis; this has confirmed the result achieved by GC-Ms analysis and thus validated the ferruginol compound showed in Figs. 5-6 and Tables 5 and 6. DART-MS with the characters of rapid quantification, active compounds screening, and has offered a new research tool for herbal medicines to complete the experimental process in a very simple way [85].

\section{Identification of Podophyllotoxin}

Podophyllotoxin is secondary metabolites with potent pharmaceutical applications in cancer therapy [86, 87]. However, the availability of podophyllotoxin from its current natural source, Podophyllum hexandrum Royle is limited. Hence, alternative sources are urgently needed $[86,88]$. In this present study, Podophyllotoxin were initially investigated in callus and shoots of Juniperus procera using HPLC and podophyllotoxin standard by

Table 6 Main constituents (1.25-1.60 min) of in vitro callus extract of Juniperus procera detected by DART-ToF-MS.

\begin{tabular}{lllllll}
\hline $\mathbf{N}^{\mathbf{0}}$ & Experimental mass & Calculated mass & Mass difference $(\mathbf{m m u})$ & Formula & Unsaturation degree & Probable Compound \\
\hline 1 & 285.22205 & 285.22184 & 0.21 & $\mathrm{C}_{20} \mathrm{H}_{29} \mathrm{O}$ & 6.5 & Ferruginol \\
2 & 286.22634 & 286.22519 & 1.15 & $\mathrm{C}_{19}{ }^{13} \mathrm{CH}_{29} \mathrm{O}$ & 6.5 & \\
3 & 287.22853 & 287.22855 & -0.02 & $\mathrm{C}_{18}{ }^{13} \mathrm{C}_{2} \mathrm{H}_{29} \mathrm{O}$ & 6.5 & \\
4 & 288.22940 & 288.23190 & -2.50 & $\mathrm{C}_{17}{ }^{13} \mathrm{C}_{3} \mathrm{H}_{29} \mathrm{O}$ & 6.5 & Podophyllotoxin \\
5 & 414.25386 & & & $\mathrm{C}_{22} \mathrm{H}_{22} \mathrm{O}_{8}$ & & \\
\hline
\end{tabular}




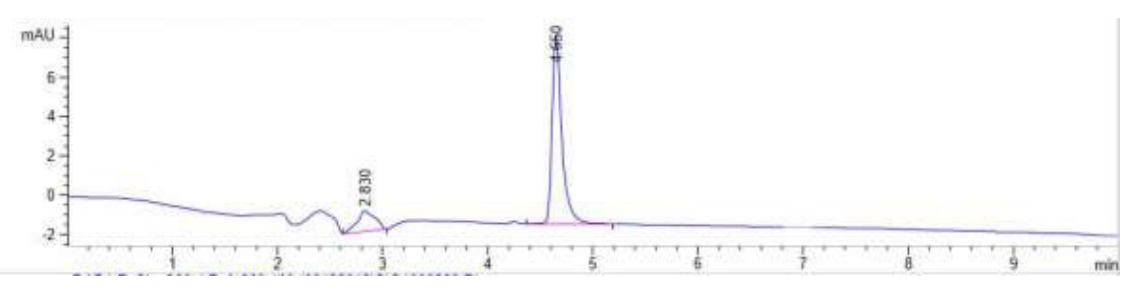

a

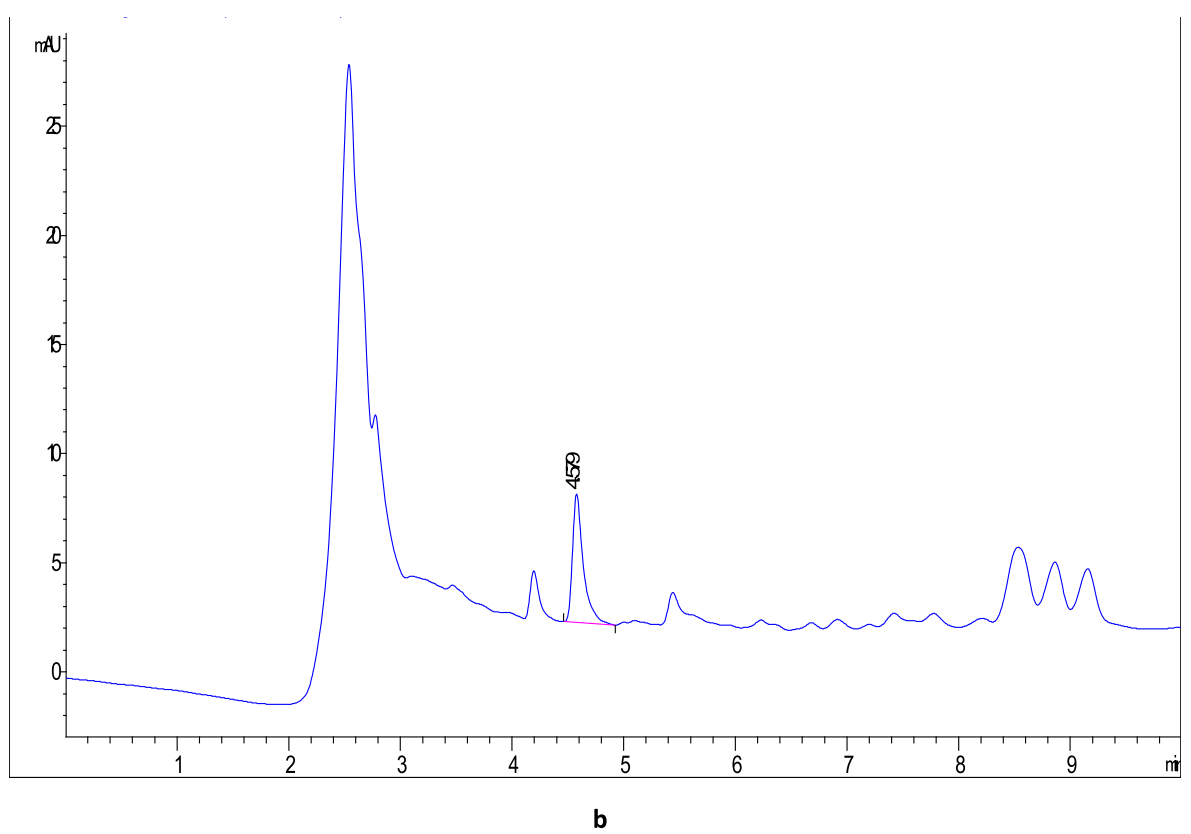

Fig. 7 (a) HPLC chromatograms podophyllotoxin standard (at $290 \mathrm{~nm}$ ) (b) HPLC chromatograms podophyllotoxin in callus extract (at $290 \mathrm{~nm}$ )

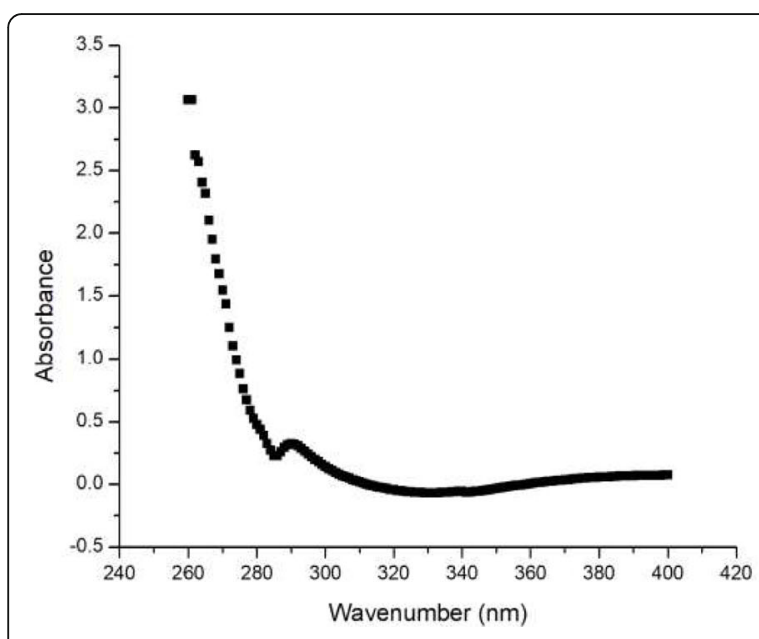

a

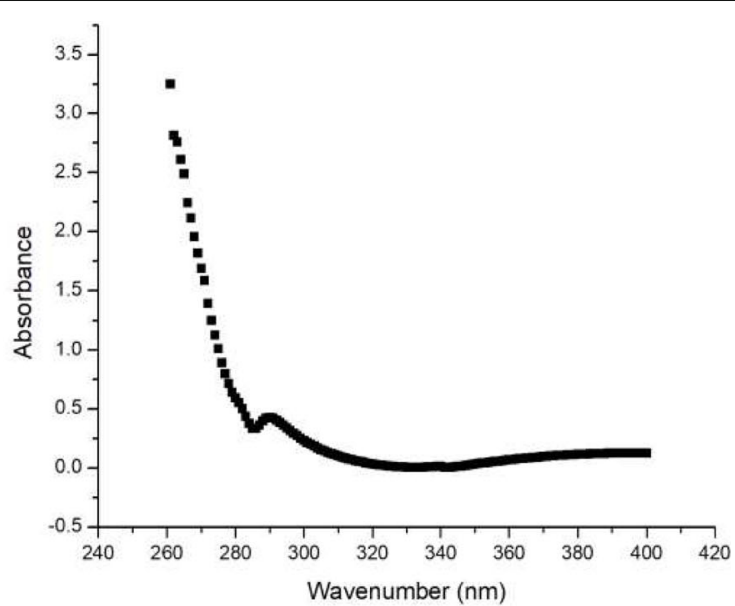

b

Fig. 8 (a) UV spectra of Podophyllotoxin standard and (b) UV spectra of Podophyllotoxin in callus extract 
comparison of their retention times (Fig. 7, a and b). The result revealed that callus material of Juniperus procera is contained novel anticancer agent (PTOX) while not detected in Shoots of Juniperus procera in vitro. The callus induction from vegetative part can increase the bioactive compounds or even generate new ones. This is in agreement with findings of [89] who has been stated that, callus cultures of Byrsonima verbascifolia (L.) DC. is a new of source of bioactive compounds. The retention time of podophyllotoxin standard was $4.6 \mathrm{~min}$ as shown in (Fig. 7, a). So far, the identification of PTOX in callus was confirmed by comparing UV spectra of standard and callus extract. The UV-Visible analysis was performed by SHIMADZU SPECTROPHOTOMETER (UV -1800 ) in the range of $200-400 \mathrm{~nm}$. The UV-Visible analysis of PTOX in callus showed that an absorption peak of PTOX at $290 \mathrm{~nm}$ (Fig. 8, b) and corresponding well with sigma PTOX standard (Fig. 8, a). Our findings match well with result reported by [90] who has been mentioned that, PTOX UV spectra peak at $290 \mathrm{~nm}$. According to literature, podophyllotoxin has been found in some species of Juniperus at low levels in most cases reported by [86]. Furthermore, the result of DART TOFMS showed that, callus of Juniperus procera contained podophyllotoxin (wt. 414.25) Fig. 6.

\section{Conclusions}

To date, there has been no report related to J. procera in vitro propagation. Therefore, this study demonstrated the first callus induction and shoot multiplication of J. procera indicates that the in vitro propagation of this important, endangered, medicinal plant is possible. We successfully conducted in vitro shoot multiplication and callus induction from $J$. procera seedlings using WPM and a different combination of PGRs. The combination of IAA and BAP at $0.5 \mu \mathrm{M}$ of both was the best PGR combination on WPM for shoot multiplication and shoot survival rates, while callus induction, quality, and optimization was $0.5 \mu \mathrm{M}$ of both 2,4-D and BAP. In vitro propagation of $J$. procera creates significant advantages to overcome the difficulties of seeds dormancy for the reproduction of plants, conservation of trees, and getting mass propagation material for pharmaceutical studies. GC-MS and HPLC analysis of shoot and callus extract of J. procera has been provided many antitumor and antibacterial constituents, and among them are PTOX and ferruginol. The findings have been confirmed by UV spectrophotometer and Direct Analysis in Real Time, Time of Flight Mass Spectrometry. This result may contribute to the production of in vitro raised plants in large quantities for production of phytochemicals and medicinal constituents (new natural source for an important secondary metabolites), serving also conservation purposes in Saudi Arabia and elsewhere. More research should be conducted on root regeneration of this plant because it will increase the survival rate and conservation of these plants and counteract the difficulties of reproduction from seeds as a consequence of the low germination rate due to seed dormancy, the underdevelopment of seeds, and the problem of dieback. Therefore, in vitro propagation and vegetative reproduction could provide promising solutions.

\begin{abstract}
Abbreviations
2,4-D: 2,4-dichlorophenoxyacetic acid; BAP: benzylaminopurine; MS: Murashige and Skoog medium [36]; WPM: Woody plant medium, Lloyd and McCown [35]; B5: Gamborg's B-5 Basal Medium, devolved by Gamborg, et. al. [37]; N6: Chu (N6) Basal Salt Mixture [38]; IAA: Indole Acetic acid; IBA: Indole-3-butyric acid; PGRs: Plant Growth Regulators;

PTOX: Podophyllotoxin; GC-MS: Gas chromatography-mass spectrometry; RT: Retention time; DART-ToF-MS: Direct Analysis in Real Time, Time of Flight Mass Spectrometry
\end{abstract}

\section{Acknowledgements}

Not applicable.

\section{Authors 'contributions}

A.M.S. was responsible for the conceptualization and has significantly contributed to all sections; A.M.S., S.K. and M.N. proposed and planned the work; A.M.S., H.S., S. A., A. A., N. A. methodology; M. T (Mohammed Tarroum) analyzed the Data and performed the Figures; A.M.S. writing-original manuscript; F.A. supervised the work. The author(s) read and approved the final manuscript.

\section{Funding}

The authors extend their appreciation to the Deputyship for Research \& Innovation, "Ministry of Education in Saudi Arabia for funding this research work through the project number IFKSURG-014.

Availability of data and materials

The data used or analyzed during the present study are available from the corresponding author/KSU.

\section{Declarations}

Ethics approval and consent to participate

Not applicable.

Consent for publication

Not applicable.

\section{Competing interests}

The authors declare no conflict of interest.

\section{Author details}

${ }^{1}$ Botany and Microbiology Department, College of Science King Saud University, P. O. BOX 2455, Riyadh 11451, Saudi Arabia. ${ }^{2}$ Department of Biology, College of Science, Imam Abdulrahman Bin Faisal University, P.O. Box 383, Dammam, Saudi Arabia.

Received: 26 January 2021 Accepted: 24 March 2021

Published online: 21 April 2021

\section{References}

1. Hazubska-Przybył T. Propagation of Juniper species by plant tissue culture: a mini-review. Forests. 2019;10(11):1028. https://doi.org/10.3390/f10111028.

2. Loureiro J, Capelo A, Brito G, Rodriguez E, Silva S, Pinto G, et al. Micropropagation of Juniperus phoenicea from adult plant explants and analysis of ploidy stability using flow cytometry. Biol Plant. 2007;51(1):7-14 https://doi.org/10.1007/s10535-007-0003-2.

3. Mujwah AA, Mohammed MA, Ahmed MH. First isolation of a flavonoid from Juniperus procera using ethyl acetate extract. Arab J Chem. 2010;3(2):85-8. https://doi.org/10.1016/j.arabjc.2010.02.003.

4. Nuñez YO, Salabarria IS, Collado IG, Hernández-Galán R. Screening Study of Potential Lead Compounds for Natural Product Based Fungicides from Juniperus lucayana. Nat Product Commun. 2008;3(4):1934578X0800300401. 
5. Tumen I, Eller FJ, Clausen CA, Teel JA. Antifungal activity of heartwood extracts from three Juniperus species. BioResources. 2013;8(1):12-20.

6. Abdel Ghany T, Hakamy OM. Juniperus procera as food safe additive, their antioxidant, anticancer and antimicrobial activity against some food-borne bacteria. J Biol Chem Research. 2014;31(2):668-77.

7. Bitew D. Assessment of the inhibitory activity of resin from Juniperus procera against the mycilium of Pyrofomes demidoffi. J Plant Pathol Microb. 2015;6:291.

8. Jansen PCM: Spices, condiments and medicinal plants in Ethiopia, their taxonomy and agricultural significance: Pudoc; 1981.

9. Ahani $\mathrm{H}$, Jalilvand $\mathrm{H}$, Nasr SMH, Kouhbanani HS, Ghazi MR, Mohammadzadeh H. Reproduction of juniper (Juniperus polycarpos) in Khorasan Razavi, Iran. Forest Science and Practice. 2013;15(3):231-7. https:// doi.org/10.1007/s11632-013-0307-6.

10. Tounekti T, Mahdhi M, Khemira H. Ethnobotanical study of indigenous medicinal plants of Jazan region, Saudi Arabia. Evidence-Based Complement Alter Med. 2019;2019.

11. Abdelghany T, Hassan MM, El-Naggar MA, Abd El-Mongy M. GC/MS analysis of Juniperus procera extract and its activity with silver nanoparticles against Aspergillus flavus growth and aflatoxins production. Biotechnol Rep. 2020;27: e00496. https://doi.org/10.1016/j.btre.2020.e00496.

12. Dessie G: Forest decline in south Central Ethiopia: extent, history and process. Institutionen för naturgeografi och kvartärgeologi; 2007.

13. Cantos M, Cuerva J, Zárate R, Troncoso de Arce a: embryo rescue and development of Juniperus oxycedrus subsp. oxycedrus and macrocarpa. In: 1998. International Seed Testing Association.

14. Mamo N, Nigusie D, Tigabu M, Teketay D, Fekadu M. Longevity of Juniperus procera seed lots under different storage conditions: implications for ex situ conservation in seed banks. J For Res. 2011;22(3):453-9. https://doi.org/10.1 007/s11676-011-0187-3.

15. Negash L: Indigenous Trees of Ethiopia: Biology, Uses and Propagation. Addis Ababa: Department of Biology, Addis Ababa University Printed: SLU Reprocentralen, Umea (Sweden) 1995.

16. Teketay D: Seed ecology and regeneration in dry afromontane forests of Ethiopia. 1998

17. Mohammadi Zade M, Kiadaliri H, Etemad V, Mehregan I, Azizinezhad R. Seed viability changes during fruit ripening of Juniperus polycarpos: implications for seed collection. Egypt J Bot. 2018;58(3):437-44.

18. Ortiz PL, Arista M, Talavera S. Low reproductive success in two subspecies of Juniperus oxycedrus L. Int J Plant Sci. 1998;159(5):843-7. https//doi.org/10.1086/297605.

19. Sriskandarajah S, Goodwin PB, Speirs J. Genetic transformation of the apple scion cultivar 'delicious' viaAgrobacterium tumefaciens. Plant Cell Tissue Organ Cult. 1994;36(3):317-29. https://doi.org/10.1007/BF00046089.

20. Aref IM, Khan PR, Khan S, El-Atta H, Ahmed Al, lqbal M. Modulation of antioxidant enzymes in Juniperus procera needles in relation to habitat environment and dieback incidence. Trees. 2016;30(5):1669-81. https://doi. org/10.1007/s00468-016-1399-0.

21. Abrha $H$, Birhane $E$, Hagos $H$, Manaye A. Predicting suitable habitats of endangered Juniperus procera tree under climate change in northern Ethiopia. J Sustain For. 2018:37(8):842-53. https://doi.org/10.1080/10549811.2018.1494000.

22. Francis SV, Senapati SK, Rout GR. Rapid clonal propagation of Curculigo orchioides Gaertn., an endangered medicinal plant. In Vitro Cell Dev BiolPlant. 2007;43(2):140-3. https://doi.org/10.1007/s11627-007-9041-x.

23. Joshi P, Dhawan V. Axillary multiplication of Swertia chirayita (Roxb. Ex Fleming) H. karst., a critically endangered medicinal herb of temperate Himalayas. In Vitro Cell Dev Biol-Plant. 2007;43(6):631-8. https://doi.org/10.1 007/s11627-007-9065-2.

24. Sivanesan I, Jeong BR. Direct shoot regeneration from nodal explants of Sida cordifolia Linn. In Vitro Cell Dev Biol-Plant. 2007:43(5):436-41. https:// doi.org/10.1007/s11627-007-9090-1.

25. Gonçalves $S$, Fernandes L, Romano A: High-frequency in vitro propagation of the endangered species Tuberaria major. Plant Cell, Tissue and Organ Culture (PCTOC) 2010, 101(3):359-363.

26. Offord CA, Tyler JL: In vitro propagation of Pimelea spicata R. Br (Thymelaeaceae), an endangered species of the Sydney region, Australia. Plant Cell, Tissue and Organ Culture (PCTOC) 2009, 98(1):19-23.

27. Javeed Q, Perveen R, llahi I. Propagation of Juniperus polycarpos C. Koch through tissue culture. I. Induction of callus. Pak J For. 1980; 30(2):72-7.

28. Zaidi MA, Khan S, Jahan N, Yousafzai A, Mansoor A. Micropropagation and conservation of three Juniperus species (Cupressaceae). Pak J Bot. 2012:44(Suppl. 1): $301-4$.
29. Gomez M, Segura J. Factors controlling adventitious bud induction and plant regeneration in matureJuniperus oxycedrus leaves cultured in vitro. In Vitro-Plant. 1994;30(4):210-8. https://doi.org/10.1007/BF02823034.

30. Negussie A. In vitro induction of multiple buds in tissue culture of Juniperus excelsa. For Ecol Manag. 1997;98(2):115-23. https://doi.org/10.1016/S03 78-1127(97)00034-0.

31. Khater $N$, Benbouza $H$. Preservation of Juniperus thurifera $L$ : a rare endangered species in Algeria through in vitro regeneration. J For Res. 2019; 30(1):77-86. https://doi.org/10.1007/s11676-018-0628-3.

32. Gomez M, Segura J. Axillary shoot proliferation in cultures of explants from mature Juniperus oxycedrus trees. Tree Physiol. 1995;15(9):625-8. https://doi. org/10.1093/treephys/15.9.625.

33. Harry IS, Pulido CM, Thorpe TA. Plantlet regeneration from mature embryos of Juniperus cedrus. Plant Cell Tissue Organ Cult. 1995;41(1):75-8. https://doi. org/10.1007/BF00124090.

34. Hussain MS, Fareed S, Saba Ansari M, Rahman A, Ahmad IZ, Saeed M. Current approaches toward production of secondary plant metabolites. J Pharm Bioallied Sci. 2012;4(1):10-20. https://doi.org/10.4103/0975-7406.92725.

35. Lloyd G, McCown B. Woody Plant medium: a mineral nutrient formulation for microculture of woody plant species. HortScience. 1981;16:453.

36. Murashige T, Skoog F. A revised medium for rapid growth and bio assays with tobacco tissue cultures. Physiol Plant. 1962;15(3):473-97. https://doi. org/10.1111/j.1399-3054.1962.tb08052.x.

37. Gamborg OL, Eveleigh D. Culture methods and detection of glucanases in suspension cultures of wheat and barley. Can J Biochem. 1968;46(5):417-21. https://doi.org/10.1139/068-063.

38. Chu C-C, C-C WANG, Sun C-S, HSU C, K-C YIN, F-Y BI. Establishment of an efficient medium for anther culture of rice through comparative experiments on the nitrogen sources. Sci Sinica. 1975;18(5):659-68.

39. Castro MR, Belo AF, Afonso A, Zavattieri MA. Micropropagation of Juniperus navicularis, an endemic and rare species from Portugal SW coast. Plant Growth Regul. 2011;65(2):223-30. https://doi.org/10.1007/s10725-011-9590-1.

40. Gomez M, Segura J. Morphogenesis in leaf and single-cell cultures of mature Juniperus oxycedrus. Tree Physiol. 1996;16(8):681-6. https://doi.org/1 0.1093/treephys/16.8.681.

41. Gomez MP, Segura J. In vitro control of adventitious bud differentiation by inorganic media components in leaves of matureJuniperus oxycedrus. In Vitro Cellular \& Developmental Biology-Plant. 1995;31(4):179-82. https://doi. org/10.1007/BF02632017.

42. Muranaka T, Miyata M, Ito K, Tachibana S. Production of podophyllotoxin in Juniperus chinensis callus cultures treated with oligosaccharides and a biogenetic precursor in honour of professor GH Neil towers 75th birthday. Phytochemistry. 1998:49(2):491-6. https//doi.org/10.1016/50031-9422(98)00295-7.

43. Karuppusamy S. A review on trends in production of secondary metabolites from higher plants by in vitro tissue, organ and cell cultures. J Med Plants Res. 2009;3(13):1222-39.

44. Espinosa-Leal CA, Puente-Garza CA, García-Lara S. In vitro plant tissue culture: means for production of biological active compounds. Planta. 2018; 248(1):1-18. https://doi.org/10.1007/s00425-018-2910-1.

45. Bokaeian M, Saboori E, Saeidi S, Niazi AA, Amini-Borojeni N, Khaje H, et al. Phytochemical analysis, antibacterial activity of Marrubium vulgare $\mathrm{L}$ against Staphylococcus aureus in vitro. Zahedan J Res Med Sci. 2014;16(10):60-4.

46. Trust T, Bartlett KH. Antibacterial activity of tropilidine and tropone. Antimicrob Agents Chemother. 1975;8(3):381-3. https://doi.org/10.1128/AAC.8.3.381.

47. de Rodríguez DJ. Salas-Méndez EdJ, Rodríquez-García R, Hernández-Castillo F, Díaz-Jiménez M, Sáenz-Galindo a, González-Morales S, Flores-López M, Villarreal-Quintanilla J, Peña-Ramos F: antifungal activity in vitro of ethanol and aqueous extracts of leaves and branches of Flourensia spp. against postharvest fungi. Ind Crop Prod. 2017;107:499-508.

48. Chavan MJ, Wakte PS, Shinde DB. Analgesic and anti-inflammatory activities of the sesquiterpene fraction from Annona reticulata L. bark. Nat Prod Res. 2012;26(16):1515-8. https://doi.org/10.1080/14786419.2011.564583.

49. Hughes N, Phillips D. 32P-postlabelling analysis of the covalent binding of benzo [ghi] perylene to DNA in vivo and in vitro. Carcinogenesis. 1993;14(1): 127-33. https://doi.org/10.1093/carcin/14.1.127.

50. Mandal S, Das N. Biodegradation of perylene and benzo [ghi] perylene (5-6 rings) using yeast consortium: kinetic study, enzyme analysis and degradation pathway. J Environ Biol. 2018:39(1):5-15. https://doi.org/10.22438/jeb/39/1/MRN-540.

51. Zhu H, Liu G, Cao F, Sheng J, Zhou B. Volatile components of pecan leaves from different cultivars of Carya illinoensis Koch. Journal of Essential Oil Bearing Plants. 2013;16(2):144-50. https://doi.org/10.1080/0972060X.2013.794049. 
52. Park E-S, Moon W-S, Song M-J, Kim M-N, Chung K-H, Yoon J-S. Antimicrobial activity of phenol and benzoic acid derivatives. Int Biodeterior Biodegradation. 2001;47(4):209-14. https://doi.org/10.1016/S0964-8305(01)00058-0.

53. Gadgoli C, Mishra S. Antihepatotoxic activity of p-methoxy benzoic acid from Capparis spinosa. J Ethnopharmacol. 1999;66(2):187-92. https://doi. org/10.1016/S0378-8741(98)00229-3.

54. Lago JHG, Ramos CS, Casanova DCC. Morandim AdA, Bergamo DCB, Cavalheiro AJ, Bolzani VdS, Furlan M, Guimaraes EF, Young MCM: benzoic acid derivatives from Piper species and their Fungitoxic activity against Cladosporium c ladosporioides and C. s phaerospermum. J Nat Prod. 2004; 67(11):1783-8. https://doi.org/10.1021/np030530j.

55. Koc AN, Silici S, Mutlu-Sariguzel F, Sagdic O. Antifungal activity of propolis in four different fruit juices. Food Technol Biotechnol. 2007;45(1):57-61.

56. Orfanos CE, Zouboulis CC, Almond-Roesler B, Geilen CC. Current use and future potential role of retinoids in dermatology. Drugs. 1997;53(3):358-88. https://doi.org/10.2165/00003495-199753030-00003.

57. Verschoore M, Bouclier M, Czernielewski J, Hensby C. Topical retinoids: their uses in dermatology. Dermatol Clin. 1993;11(1):107-15. https://doi.org/10.1 016/S0733-8635(18)30287-0.

58. Darlenski R, Surber C, Fluhr J. Topical retinoids in the management of photodamaged skin: from theory to evidence-based practical approach. $\mathrm{Br} J$ Dermatol. 2010;163(6):1157-65. https://doi.org/10.1111/j.1365-2133.2010.09936x.

59. Liu H, Huang J, Yang S, Li J, Zhou L. Chemical composition, algicidal, antimicrobial, and antioxidant activities of the essential oils of Taiwania flousiana Gaussen. Molecules. 2020;25(4):967. https://doi.org/10.3390/ molecules25040967.

60. Uzel A, Önçağ Ö, Çoğulu D, Gençay Ö. Chemical compositions and antimicrobial activities of four different Anatolian propolis samples. Microbiol Res. 2005;160(2):189-95. https://doi.org/10.1016/j.micres.2005.01.002.

61. Joo JC, Khusnutdinova AN, Flick R, Kim T, Bornscheuer UT, Yakunin AF, et al. Alkene hydrogenation activity of enoate reductases for an environmentally benign biosynthesis of adipic acid. Chem Sci. 2017;8(2):1406-13. https://doi. org/10.1039/C6SC02842J.

62. Labrie F, Derogatis L, Archer DF, Koltun W, Vachon A, Young D, et al. Effect of intravaginal prasterone on sexual dysfunction in postmenopausal women with vulvovaginal atrophy. J Sex Med. 2015;12(12):2401-12. https://doi.org/1 $0.1111 /$ jsm.13045.

63. Florez DHÂ, dos Santos Moreira AM, da Silva PR, Brandão R, Borges MMC, de Santana FJM, et al. Desomorphine (Krokodil): an overview of its chemistry, pharmacology, metabolism, toxicology and analysis. Drug Alcohol Depend. 2017; 173:59-68. https://doi.org/10.1016/j.drugalcdep.2016.12.021.

64. Mizushina Y, Yoshida S, Matsukage A, Sakaguchi K: The inhibitory action of fatty acids on DNA polymerase $\beta$. Biochimica et Biophysica Acta (BBA)General Subjects 1997, 1336(3):509-521.

65. Chinwe SA, Anyakora C, Ota D, De Waard M, Coker H: GC-MS analysis, antiinflammatory and anti-seizure effects of n-octanoic acid from special breed palm kernel nut oil. Planta Med 2014, 80(10):PD118.

66. Wei Y, He J, Qin H, Xa W, Yao X. Determination of ferruginol in rat plasma via high-performance liquid chromatography and its application in pharmacokinetics study. Biomed Chromatogr. 2009;23(10):1116-20. https:// doi.org/10.1002/bmc.1232.

67. Xiong WD, Gong J, Xing C. Ferruginol exhibits anticancer effects in OVCAR-3 human ovary cancer cells by inducing apoptosis, inhibition of cancer cell migration and G2/M phase cell cycle arrest. Mol Med Rep. 2017;16(5):70137. https://doi.org/10.3892/mmr.2017.7484.

68. González MA, Clark J, Connelly M, Rivas F. Antimalarial activity of abietane ferruginol analogues possessing a phthalimide group. Bioorg Med Chem Lett. 2014;24(22):5234-7. https://doi.org/10.1016/j.bmcl.2014.09.061.

69. Molnar J, Sakagami H, Motohashi N. Diverse biological activities displayed by phenothiazines, benzo [a] phenothiazines and benz [c] acridins. Anticancer Res. 1993;13(4):1019-25.

70. Motohashi N, Sakagami H, Kurihara T, Ferenczy L, Csuri K, Molnar J. Antimicrobial activity of phenothiazines, benzo [a] phenothiazines and benz [c] acridines. Anticancer Res. 1992;12(4):1207-10.

71. Wiles JA, Bradbury BJ, Pucci MJ. New quinolone antibiotics: a survey of the literature from 2005 to 2010. Expert opinion on therapeutic patents. 2010; 20(10):1295-319. https://doi.org/10.1517/13543776.2010.505922.

72. King DE, Malone R, Lilley SH. New classification and update on the quinolone antibiotics. Am Fam Physician. 2000;61(9):2741-8.

73. Katerere DR, Gray Al, Nash RJ, Waigh RD. Phytochemical and antimicrobial investigations of stilbenoids and flavonoids isolated from three species of
Combretaceae. Fitoterapia. 2012;83(5):932-40. https://doi.org/10.1016/j. fitote.2012.04.011.

74. Villamizar JE, Angarita AY, Blanco FE, Taylor PG, Salazar FJ. Synthesis of novel podocarpa-8, 11, 13-triene-7-and 13-nitriles and evaluation of their antiinflammatory and cytotoxic activity. J Chem Res. 2016;40(8):502-5. https:// doi.org/10.3184/174751916X14682323381549.

75. Pham TD, Ziora ZM, Blaskovich MA. Quinolone antibiotics. Medchemcomm. 2019;10(10):1719-39. https://doi.org/10.1039/C9MD00120D.

76. Ling H-B, Chen Z-S, Yang F, Xu B, Gao J-M, Ji K. Gold-catalyzed oxidation terminal alkyne: an approach to synthesize substituted Dihydronaphthalen-2 (1 H)-ones and Phenanthrenols. The Journal of organic chemistry. 2017; 82(13):7070-6. https://doi.org/10.1021/acs.joc.7b01244.

77. Sun W, Li K, Liu H, Gu Y, Zhang Y, You Z, et al. Synthesis, characterization, crystal structures, and antibacterial activity of polynuclear nickel (II) and copper (II) complexes with similar tridentate Schiff bases. Russ J Coord Chem. 2017:43(10):693-9. https://doi.org/10.1134/S1070328417100104.

78. Xi J, Xu S, Zhang L, Bi X, Ren Y, Liu Y-C, et al. Design, synthesis and biological activity of 4-(4-benzyloxy) phenoxypiperidines as selective and reversible LSD1 inhibitors. Bioorg Chem. 2018;78:7-16. https://doi.org/10.1016/.bioorg.2018.02.016.

79. Wood AW, Levin W, Chang RL, Huang M-T, Ryan DE, Thomas PE, et al. Mutagenicity and tumor-initiating activity of cyclopenta $(c, d)$ pyrene and structurally related compounds. Cancer Res. 1980;40(3):642-9.

80. Ma W, Zhang Y, Ding Y-Y, Liu F, Li N. Cytotoxic and anti-inflammatory activities of phenanthrenes from the medullae of Juncus effusus $L$. Arch Pharm Res. 2016;39(2):154-60. https://doi.org/10.1007/s12272-015-0680-x.

81. Mikaia A, El PEW, EI VZ, El DZ, El ODS, Neta P, RI IZ, Linstrom P, Mirokhin Y, Tchekhovskoi D: NIST standard reference database 1A. 2014.

82. Kuroda K, Fujiwara T, Hashida K, Imai T, Kushi M, Saito K, et al. The accumulation pattern of ferruginol in the heartwood-forming Cryptomeria japonica xylem as determined by time-of-flight secondary ion mass spectrometry and quantity analysis. Ann Bot. 2014;113(6):1029-36. https:// doi.org/10.1093/aob/mcu028.

83. Muhammad I, Mossa JS, El-Feraly FS. Additional antibacterial diterpenes from the bark of Juniperus procera. Phytother Res. 1996;10(7):604-7. https:// doi.org/10.1002/(SICI)1099-1573(199611)10:7<604:.AID-PTR922>3.0.CO;2-C.

84. Bisacchi GS. Origins of the quinolone class of antibacterials: an expanded "discovery story" miniperspective. J Med Chem. 2015;58(12):4874-82. https:// doi.org/10.1021/jm501881c.

85. Cody RB, Fouquet TN, Takei C: Thermal desorption and pyrolysis direct analysis in real time mass spectrometry for qualitative characterization of polymers and polymer additives. Rapid Commun Mass Spectrom 2020:e8687.

86. Renouard S, Lopez T, Hendrawati O, Dupre P, Doussot J, Falguieres A, et al. Podophyllotoxin and deoxypodophyllotoxin in Juniperus bermudiana and 12 other Juniperus species: optimization of extraction, method validation, and quantification. J Agric Food Chem. 2011;59(15):8101-7. https:/doi.org/10.1021/jf201410p.

87. Canel C, Moraes RM, Dayan FE, Ferreira D. Podophyllotoxin. Phytochemistry. 2000;54(2):115-20. https://doi.org/10.1016/S0031-9422(00)00094-7.

88. Koulman A, Quax WJ, Pras N: Podophyllotoxin and related lignans produced by plants. Biotechnology of Medicinal Plants: Vitalizer and Therapeutic; Ramawat, KG, Ed 2004:225-266.

89. Castro AHF. Braga KdQ, Sousa FMd, Coimbra MC, Chagas RCR: callus induction and bioactive phenolic compounds production from Byrsonima verbascifolia (L.) DC.(Malpighiaceae). Rev Ciênc Agron. 2016;47(1):143-51.

90. Kamal A, Singh M, Ahmad F, Saleem K, Ahmad S. A validated HPTLC method for the quantification of podophyllotoxin in Podophyllum hexandrum and etoposide in marketed formulation. Arab J Chem. 2017;10: S2539-46. https://doi.org/10.1016/j.arabjc.2013.09.027.

\section{Publisher's Note}

Springer Nature remains neutral with regard to jurisdictional claims in published maps and institutional affiliations. 